\title{
The Implementation of Tree Method in Geographic Information System of Mother Temple Mapping and its Linkages based on Web
}

\author{
I Nyoman Piarsa \\ Department of Information \\ Technology, Udayana \\ University, Bali, Indonesia
}

\author{
I Gede Udayana Putra \\ Department of Information \\ Technology, Udayana \\ University, Bali, Indonesia
}

\author{
A. A. K. Sudana \\ Department of Information \\ Technology, Udayana \\ University, Bali, Indonesia
}

\begin{abstract}
Mother Temple is one category of shrine trust places in tenet of Hinduism in Bali. Mother Temple is a holy place where Balinese Hinduism worship the ancestor based on their lineage ancestor. In the tenet of Hinduism, the worship of ancestors is a thing that should not be forgotten. Therefore, Mother Temple is special place as a place of worship of Hindus who have blood ties in accordance with the lineage. Mother Temple can be categorized into five, namely, Pedharman Temple, Kawitan Temple, Panti Temple, Merajan / Sanggah Gede and Merajan / usual Sanggah. Generally in Bali, there is more than one Mother Temple and those have a relationship regarding to the level with one another based on their offspring. The Implementation of Tree Method in Geographic Information System of Mother Temple Mapping and its Linkages is a useful idea in order to connect all levels of Mother Temple with its linkage in Bali and in order to provide correct and clear linkages information. The meaning of linkage in this context is a relationship that is created among the data with other data. The method applied as the connecting link is a Tree method which is a basic modeling concept that can maximize the linkage process.
\end{abstract}

\section{Keywords}

Geographic Information System, Mother Temple, Tree Method, Linkages

\section{INTRODUCTION}

Hinduism in Bali recognize holy place or temple as a place to worship for their ancestors namely Mother Temple. Mother Temple is a holy place of worship ancestral spirits of Hinduism who have wit relation or lineage ancestor, so Mother Temple is special place as a place of worship of Hindus who have blood ties in accordance with the lineage [1]. Every Hindus in Bali regularly worship in Mother Temple annually in order to commemorate a temple ceremony (temple's anniversary).

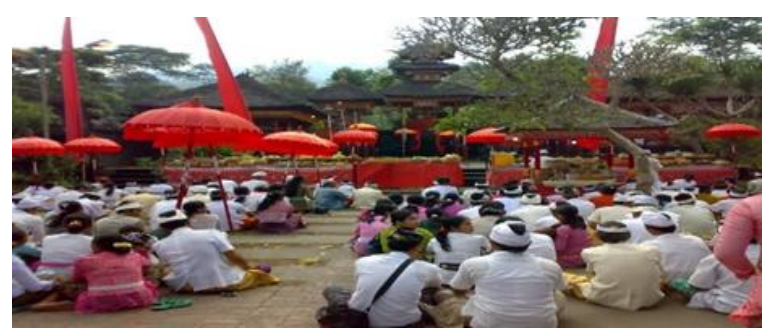

Figure 1: The example of worship in Mother Temple.

One kinds of information needed by societies at this time is geographic information. Geographic Information System
(GIS) is a highly developed geographical technology. Geographic Information System is a specialized information system that allows for data processing of spatial and nonspatial become related information about the earth and used for collection, storage, manipulation, analysis and display of geographic data that is extremely useful for decision making in resolving a problem in space certain earth [2]. The development of Internet technology influences GIS technology. GIS technology can be built with Web-based. Web GIS is a form of a website that describes an area of geographic information, such as Mother Temple.

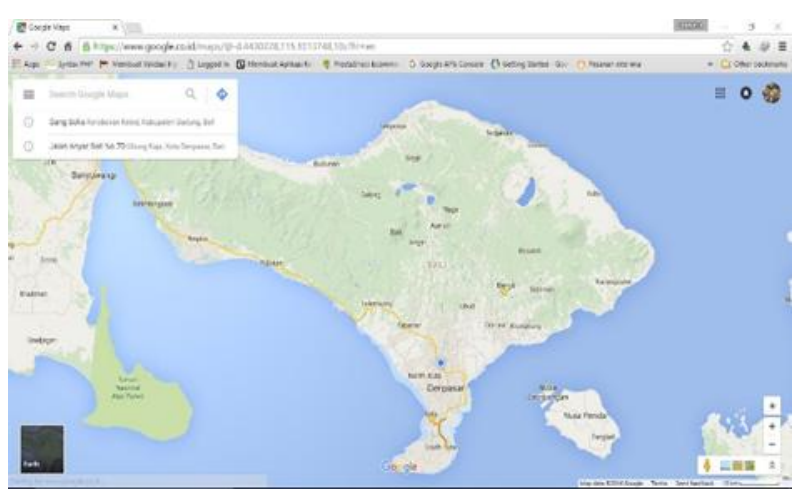

Figure 2: The example of Digital Google Maps.

The rapid development of science and technology makes the occurrences of systems that can help a wide range of human needs, especially the needs of information, where each system has had a different method. Then, one of it is a Tree method or Tree Theory. Tree Theory is a theory which is very useful in modeling the structure of the data on which the applications of the theory of this tree can be used as a data storage structure is excellent in certain cases [3], as well as linked of Mother Temple.

\section{THE LITERATURE AND METHODOLOGY}

\subsection{Google Maps API}

Google Maps is the online mapping service provided by Google. Google Maps has an open source platform that can be used freely, but IT must comply with the requirements that have been set. Google Maps also provides freedom for developers to develop technology based ON mapping IN THE Google Maps [4]. In 2005, google released Google Maps API. This application is applies in order to implemented digital map which can be used for various kinds of applications [5]. Google Maps platform development used a programming language with the name of the Maps JavaScript API. Google 
Maps Application Programming Interface (API) is an application feature that is applied to facilitate the users who want to integrate Google Maps into their websites by displaying the data points of their own. Google Maps can be displayed on an external website using the Google Maps API. Maps API JavaScript must be entered in advance in order to allow the Google Maps app may appear on certain websites.

Displaying a map using the Google Maps API to the order is as follows.

a) Incorporate Maps API Javascript.

b) Conduct a div element as the location to ask questions.

c) Conduct some literal object to store properties are properties on the map.

d) Write Javascript function, to create the object map.

e) Initialize a map in the HTML body tag with onload event.

Displaying a map of Google Maps on the web and Google Maps functions can be learnt in https://developers.google.com/maps/ page. Some of the main functions that are often used are to ask questions, to ask marker, show info window, create a polygon, and make a circle.

\subsection{Geographic Information Systems}

GIS is a computer-based system applied in order to store and manipulate geographic information. GIS is designed to collect, store and analyze objects and phenomena in which the geographic location is an important characteristic or critical to be analyzed. GIS has the capability to handle referential geographic data namely data input, data management (storage and redial), analysis and manipulation of data, and output as the final result [6].

Data in GIS consists of two components, namely spatial data related to the geometry of spatial and attribute data that provide information about the spatial form [7]. The main components of GIS are a computer system, geospatial data and users. The computer system for GIS consists of hardware, software and procedures designed to support data entry, processing, analysis, modeling and display of geospatial data.

The location information or geometric property of spatial objects can be included in some form such as the following.

a) Point (Dimension Zero-Point): The point is a graphical representation or the simplest geometry for spatial objects. This representation has no dimension, but can be identified on the map and can be displayed on the monitor by using certain of the process is returned to web server and at last is accepted by the web browser. Symbols of building elements shown as polygons on a large scale map, while on the small scale are shown as point elements.

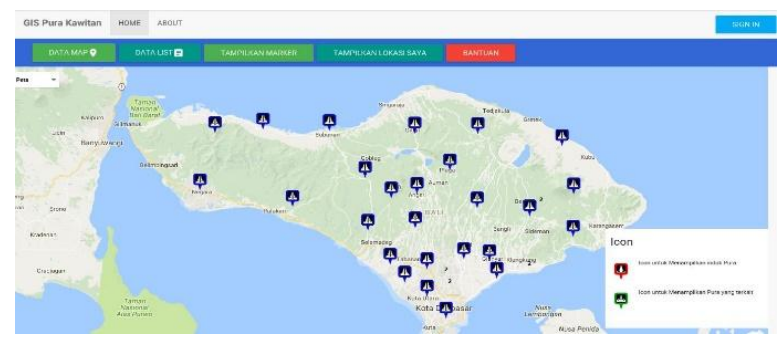

Figure 3: Spatial Data in Shape Point or Marker. b) Outline (One-Dimensional polyline): The line is a linear geometric shape that connects at least two points and is used to represent objects that are one-dimensional.

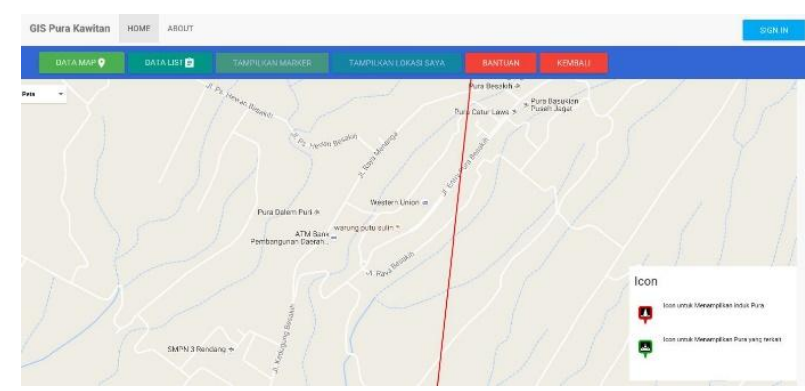

Figure 4: Spatial Data in the Form Line or Polyline.

\subsection{Web-Based Geographic Information System}

Web- based Geographic Information System is Geographic Information System application that can be run and applied into a web browser. The application can run in a global network that is the Internet, a local network or LAN network, and a computer that has a web server [2].

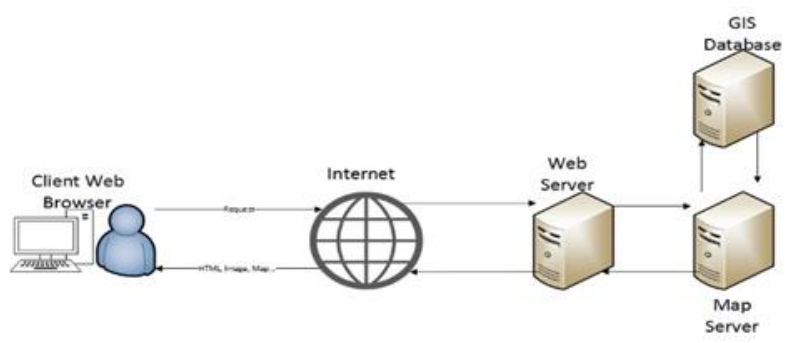

Figure 5: Architecture Geographic Information System Based On Web

Figure 5 shows the relation of the interaction between clients in the form of web browser with the server based on the scenario and response. Web browser sends request to web server. Web server requested the digital map through map server and map server ask the data from database. The result of those process will be returned back to web server and will be received by web browser.

\subsection{Tree Method}

Tree theory is quite old theory since it has been known since 1857, whereas the English mathematician Arthur Cayley used tree theory to calculate the number of chemical compounds. Actually, Tree Theory is a problem resolution mechanism by analogizing the problems into the structure of tree to facilitating in finding the solution of the problem [3]. Tree method is a method that is used in order to classify the data. This method is displayed by using tree as the model in which has relation data[8].
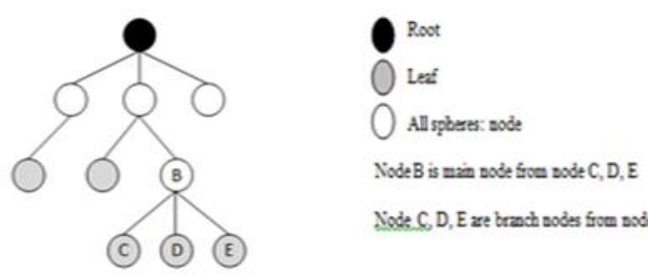

Node C, D, E ree brach sodes from sode B

Figure 5: The Illustration of Tree Method. 


\section{REFERENCES}

[1] Ktut Soebandi Jro Mangku Gde. 1998. Mengenal Leluhur Dari Dunia Babad. Denpasar: PT BP.

[2] Setiadi, I Made Dharmawan, 2015, Sistem Informasi Geografis Pemetaan Tingkat Pertumbuhan Penduduk Berbasis Web, Skripsi S.TI, Universitas Udayana.

[3] Akbar, Khoirush Sholih Ridhwaana, 2006, "Penerapan Teori Pohon Dalam Kajian Struktur Data", Insitut Teknologi Bandung.

[4] Irwansyah, E., 2011. Sistem Informasi Geografis : Prinsip Dasar dan Pengembangan Aplikasi. Yogyakarta:Digibooks Yogyakarta.

[5] Shunfu Hu and Ting Dai, "Online Map Application Development Using Google Maps API, SQL Database, and ASP.NET", International Journal of Information and
Communication Technology Research, Vol. 3, No. 3, 2013.

[6] Aronoff, S., 1989. Geographic Information Systems: A Management Perspective. Ottawa: WDL Publications.

[7] Chang, K, 2001. Introduction to Geographic Information Systems. New York : McGraw-Hill.

[8] D.Lavanya and Dr.K.Usha Rani, "Ensemble Decision Tree Classifier For Breast Cancer Data”, International Journal of Information Technology Convergence and Services (IJITCS), Vol. 2, No.1, February 2012.

[9] Frank S. C. Tseng and Wen-Ping Lin, "D-Tree: A MultiDimensional Indexing Structure for Constructing Document Warehouses*", Journal Of Information Science And Engineering, 22, 2006. 